\title{
Beware of dogs! Domestic animals as a threat for wildlife conservation in Alpine protected areas
}

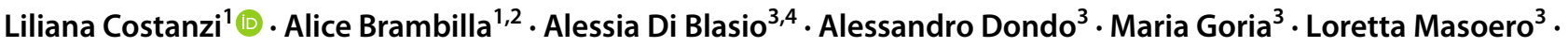 \\ Maria Silvia Gennero ${ }^{3} \cdot$ Bruno Bassano $^{1}$
}

Received: 24 November 2020 / Revised: 21 June 2021 / Accepted: 23 June 2021 / Published online: 13 July 2021

(c) The Author(s), under exclusive licence to Springer-Verlag GmbH Germany, part of Springer Nature 2021

\begin{abstract}
Diseases are natural regulating factors of wildlife populations, but some pathogens may become an important threat in wildlife conservation, especially for endangered species. The presence of domestic animals may foster the spread of diseases in natural population, although their role in the dynamic of infections in wildlife is not clear. In this study, we investigated the presence and prevalence of a range of multi-host pathogens in wild species (red fox, Eurasian badger, beech marten, pine marten, stoat for a total of 89 carcasses analysed) and domestic animals ( $n=52$ shepherd and $n=25$ companion dogs) living in a protected area of the Alps (the Gran Paradiso National Park) and discussed the role of domestic dogs as possible source of infection for wild species. Our results showed that domestic dogs are potential shedder of three important pathogens: Canine distemper virus, Toxoplasma sp. and Neospora caninum. In particular, shepherd dogs seem to represent a threat for wildlife as they are exposed to multiple pathogens because of free-roaming, scavenging lifestyles and close proximity to livestock. However, also companion dogs more subject to veterinary care may foster the spread of pathogens. Our results highlight the importance of regulating the access of domestic dogs to protected areas that aim at preserving biodiversity and enhancing the conservation of endangered species.
\end{abstract}

Keywords Domestic dogs $\cdot$ Wild carnivores $\cdot$ Protected areas $\cdot$ Multi-host pathogens $\cdot$ Zoonosis $\cdot$ Sanitary monitoring

\section{Introduction}

Infectious diseases are natural regulating factors of wildlife populations (De Almeida Curi et al. 2010), but some pathogens may become an important threat in wildlife conservation when they affect population dynamics of native species through temporary or permanent declines in abundance (Leendertz et al. 2006; Smith et al. 2006; Pedersen

Liliana Costanzi

costanzi.liliana@gmail.com

1 Alpine Wildlife Research Centre, Gran Paradiso National Park, Fraz Jamonin 5, 10080 Noasca, TO, Italy

2 Department of Evolutionary Biology and Environmental Studies, University of Zurich, Wintherturerstrasse 190, CH-8057 Zurich, Switzerland

3 Istituto Zooprofilattico Sperimentale del Piemonte, Liguria E Valle D’Aosta, Via Bologna 148, 10154 Torino, TO, Italy

4 A.S.L. TO3 - Azienda Sanitaria Locale Di Collegno E Pinerolo TO3, Via Martiri XXX Aprile 30, 10093 Collegno, TO, Italy et al. 2007; Hudson et al. 2016; Afema et al. 2017; Scheele et al. 2019). The impact of pathogens may become particularly severe when it acts in association with other environmental factors such as habitat loss, climate change, overexploitation of natural resources, invasion of alien species and environmental pollution (Smith et al. 2009; McKnight et al. 2017). Indeed, environmental conditions can have direct impacts on the distribution, life cycle and physiological status of wildlife populations, of the pathogens and, in the case of vector-borne diseases, of the vectors as well (Rizzoli et al. 2019). In addition, current climate and environmental changes are expected to alter the host-pathogenvector interactions thus representing a further potential threat for the conservation of wildlife (Gallana et al. 2013).

Some of the pathogens affecting wildlife are speciesspecific, but over $80 \%$ of domesticated animal pathogens can infect wildlife (Cleaveland et al. 2001) like canine distemper virus (CDV) (Acosta-Jamett et al. 2011), rabies virus (Randall et al. 2004) or Neospora spp. (Ballash et al. 2019). Spatial overlap between wildlife and livestock (like cows, sheep and goats) may thus increase the risk of introduction 
and spread of diseases in natural environments, especially of those caused by multi-host pathogens (Gortazar et al. 2007). In these complex contexts, disentangling the role of each potential host is extremely challenging (Haydon et al. 2002).

Carnivora is the most endangered taxa worldwide probably because of the behaviour and ecology of the species belonging to it (e.g. feeding behaviour, marked sociality, scent communication) which make them particularly susceptible to infections (Woodroffe et al. 2004). A large number of pathogens were reported to affect wild carnivores (Murray et al. 1999), and most of them were shared with domestic species causing epidemics with dramatic decline in density of endangered species (Canis simensis: Randall et al. 2004; Lycaon pictus: Gayscone et al. 1993; Canis lupus: Mech et al. 2008; Martinello et al. 1997; Randall et al. 2004; Woodroffe et al. 2004; Megid et al. 2009, 2010). Both domestic and wild canids can also be asymptomatic reservoirs of pathogens dangerous for wild ungulates such as Toxoplasma gondii, potentially abortive in wild mammals (Hill et al. 2005) and Neospora caninum, which cause spontaneous abortion in cattle and neonatal disease in a wide range of carnivore species which are definitive hosts (Dubey et al. 2007).

In much of the developed world, dog walking is a key motivation for dog owners visiting a park (Sterl et al. 2008): considering the increasing importance that domestic dogs have assumed in daily life, in many protected areas, national parks and nature reserves, the management of dogs is controversial (Walsh 2011) and often face strong opposition when trying to limit the access of tourists accompanied by dogs (B. Bassano, pers. obs.). Different but nevertheless strong oppositions are also met when trying to control shepherd dogs, despite their sanitary monitoring would be essential for wildlife health management (Pedersen et al. 2007; Smith et al. 2009).

Knowledge about the potential role of domestic dogs in the epidemiology of the most harmful wildlife disease is essential to assess management strategy. The few studies addressing this topic were conducted mainly in North America (Salb et al. 2008; Timm et al. 2009; Canuti et al. 2017), South America (Acosta-Jamett et al. 2011, 2015; Lessa et al. 2016) or Africa (Alexander and Appel 1994, Cleaveland et al. 2000; Woodroffe et al. 2012) where environmental characteristics, human habits, habitat extensions and, hence, potential overlap between wildlife and domestic animals are considerably different from, e.g. those of the Alpine region.

A scanning surveillance by means of diagnostic investigation on dead wild animals can be critical for the early detection of infectious disease, since it provides baseline information about pathogen circulation (Leighton and Working Group on Wildlife Diseases 2010). However, this approach may not be sufficient in areas where domestic animals and wild species are sympatric (Bengis et al. 2002; Fiorello et al. 2004) because the overlapping distribution strongly increases the risk of spill overs (Heinse et al. 2016). For this reason, in areas where wildlife and domestic animal ranges overlap, a monitoring of the health status of domestic animals should be carried on in addition to diagnostic investigation on dead wild animals. We therefore adopted a multidisciplinary and multi-species approach to identify possible risks for wildlife conservation posed by the presence of domestic dogs in a protected area in the North-Western Italian Alps: the Gran Paradiso National Park (GPNP). Using different diagnostic tools and opportunistic targeted sampling, we assessed the health status of domestic dogs, red foxes and mustelids living in the territory of GPNP. To aid management decisions about the risks posed by the presence of domestic dogs in Alpine protected areas, we focused on the following pathogens that may represent a serious threat for wildlife conservation (Laurenson et al. 1998; De Almeida Curi et al. 2010): canine distemper virus (CDV), canine Parvovirus (CPV), canine Coronavirus (CCV), canine Adenovirus (CAV), canine Herpesvirus (CHV), Lyssavirus, Neospora caninum, Toxoplasma spp., Leishmania spp., Leptospira spp., Salmonella spp. A brief description of the pathogens investigated, with the relative effects on the host species relevant for this study is provided hereafter.

Canine distemper virus (CDV) is one of the most important infectious microparasites of domestic and free-ranging carnivores worldwide and causes an acute or subacute highly contagious febrile disease that may include respiratory, gastrointestinal and central nervous system disease (Appel et al. 1995; Loots et al. 2017).

Canine Parvovirus (CPV) is a highly contagious pathogen primarily transmitted through contact with infected faeces (Pollock et al. 1980; McCaw and Hoskins 2006). It may cause enteric disease in canids and is often fatal in young or immunosuppressed individuals (Mech et al. 1986). Early mortality and fecundity rate decreasing are also associated with this disease in wild canids (Mech and Goyal 1993; Steinel et al. 2001; Mech et al. 2008).

Canine Coronavirus (CCV) is a highly contagious intestinal virus that typically causes outbreaks of enteritis (Tennant et al. 1993) especially in puppies less than 12 weeks of age (Saif and Heckert 1990; Ford 2003). Although CCV infections appear to be mainly asymptomatic, young puppies may be more severely affected as well as dogs with mixed infections with other viruses or bacteria (Hoskins et al. 1998).

Canine Adenovirus (CAV) can cause infectious canine hepatitis in infected canids with clinical symptoms including vomiting, diarrhoea, depression, seizures and death in severely affected individuals (Greene 1998).

Canine Herpesvirus (CHV) has a worldwide distribution. Although infection is typically asymptomatic in adults, clinical signs include abortion, respiratory infection, ataxia, anorexia, vomiting and depression (Carmichael and Greene 
1998). The prevalence and effects of CHV in wild canid populations and the pathogenicity of $\mathrm{CHV}$ remain poorly understood (Watts and Benson 2016).

Lyssavirus is the genus to which rabies virus belongs. All warm-blooded animals are vulnerable to this infection, but foxes, coyotes, jackals, wolves and certain rodents are among the most susceptible animal group (Greene and Rupprecht 2013).

Neospora caninum is a protozoan parasite described in a large number of wild Carnivora and wild mammals (Ferroglio and Rossi 2001; Bregoli et al. 2006; Gaffuri et al. 2006; Almeria et al. 2007; Billinis 2013; Panadero et al. 2010; Donahoe et al., 2015). It is considered one of the main causes of abortion and stillbirth in cattle worldwide (Dubey and Schares 2011), but little is known about the effect of the infection on wild ruminants. In wild carnivores, the infection could represent a risk for cubs, causing serious neurological symptoms (Dubey and Schares 2011).

Toxoplasma spp. are protozoan parasites that can infect a large number of mammal species (Randall et al. 2000; Aubert et al. 2010; Chaichan et al. 2017). To date, few studies correlate infection with acute mortality in wild animals (Jokelainen et al. 2011; Jokelainen and Nylund 2012).

Leishmania spp. are protozoan responsible of an emerging, serious zoonosis for many wildlife and zoo species (Sousa et al. 2014; Oleaga et at. 2018); they are transmitted by phlebotomine sand flies.

Leptospira spp. are bacteria which cause a systemic infection that affects domestic animals and wildlife, as well as humans. The infection causes abortion, mastitis and death in livestock (Bolin 2005; Grooms 2006). Feral and wild animals are reservoir hosts for leptospires and often do not exhibit clinical signs of disease (Bengis et al. 2004), but little is known about the role of wild species in the epidemiology of this disease.

Salmonella spp. are bacteria commonly found in the intestine of wild birds and in domestic cats, infected by preying on sick birds. This disease, mainly investigated as a source of infection for humans (Hilbert et al. 2012), is poorly described in wild mammals, both in terms of prevalence and of effects on survival.

\section{Material and methods}

\section{Study area}

The GPNP is a large Alpine National Park $\left(710 \mathrm{~km}^{2}\right)$ located in the North Western Italian Alps. It was established in 1922 with the aim of conserving the last surviving population of Alpine ibex (Capra ibex). In the protected area, the presence of the following carnivores and mustelids was recorded: red fox (Vulpes vulpes), Eurasian badger (Meles meles), beech marten (Martes foina), least weasel (Mustela nivalis), pine marten (Martes martes) and stoat (Mustela erminea) (Patriarca and Debernardi 1997). Since 1992, the Western Alps were re-colonized by grey wolf (Canis lupus italicus, Valière et al. 2003). The stable presence of this predator in the GPNP was documented since 2007 (Palmegiani et al. 2013).

\section{Sampling}

\section{Domestic dogs}

The health survey of shepherd dogs was carried out in 2015 and 2016. A total of 52 shepherd $\operatorname{dogs}(n=34$ males and $n=18$ females, from 3 months to 13 years old) from 24 different alpine pastures were sampled. Among the sampled dogs, 3 were regularly vaccinated, 5 were vaccinated only when puppies for parvovirosis, distemper virus, adenovirus, canine parainfluenza virus whilst 44 had never been vaccinated. The sampling was conducted during summer when shepherd dogs and livestock (mainly sheep and cattle) were in the summer Alpine pastures.

In 2018, the same sampling was extended to Park rangers' dogs working in the whole territory of the GPNP. A total of 25 dogs ( $n=7$ males and $n=18$ females, age ranging from 7 months to 12 years old) were sampled. About $60 \%(n=15)$ of them lived with other domestic animals (cats or livestock). Among Park rangers' dogs, 2 had never been vaccinated, 1 was vaccinated 9 years before the sampling, and all the other 21 were regularly vaccinated every year for parvovirosis, distemper virus, adenovirus, canine parainfluenza virus and leptospirosis.

Samples from live dogs were collected, processed and stored following the protocols provided by the Istituto Zooprofilattico Sperimentale di Piemonte, Liguria e Valle d'Aosta (IZSPLV) complying with animal welfare standards. Blood, ocular, nasal, genital and faecal samples were collected from all dogs. Blood was taken from the cephalic vein by vacuum tubes without anticoagulant and left at room temperature for $4 \mathrm{~h}$, then serum was separated by centrifugation and stored at $-18{ }^{\circ} \mathrm{C}$. Ocular, nasal and genital swabs for virological examinations were kept in viral transport media at room temperature, in order to reduce bacterial contamination. Faecal swabs were picked up in a double rate: one with viral transport media for virological examination, and the other one without medium for bacteriologic examinations. All samples were analysed by IZSPLV (see Table 1 for details on the analytical procedures). For all the dogs, anamnestic data were also recorded (sex, age, location and clinical conditions). 
Table 1 Analytical methods used to detect the presence of pathogens on different matrices (biological samples/organs) collected from red foxes, mustelids and domestic dogs in Gran Paradiso National Park between 2008 and 2018. Abbreviation for pathogens: $C A V$ canine adenovirus, $C C V$ canine coronavirus, $C P V$ canine parvovirus, $C D V$ canine distemper virus, $C H V$ canine herpesvirus; abbreviations for biological sample/organ: $C N S$ central nervous system)

\begin{tabular}{lll}
\hline Pathogen & Analytical methods & Biological sample/organ \\
\hline Salmonella sp. & Bacteriological analysis (OIE 2018a) & Faeces; liver \\
Leptospira spp. & Micro-agglutination (OIE 2008) & Serum; intra-cardiac blood; clot \\
& Real Time PCR (Stoddarda et al. 2009) & Kidney \\
Lyssavirus & Fluorescent antibody test (OIE 2018b) & CNS \\
CDV & Fluorescent antibody test (Di Blasio et al. 2019) & CNS; nasal swab; ocular swab; lung \\
& One step RT-PCR (Di Blasio et al. 2019) & CNS; lung; intra-cardiac blood; clot \\
CCV & ELISA (Di Blasio et al. 2019) & Serum \\
CPV & One step RT-PCR (Gamble et al. 1997; Pratelli et al. 1999) & Faeces \\
CAV 1-CAV 2 & Simplex PCR (Buonavoglia et al. 2001) & Faeces \\
CHV & PCR (Hu et al. 2001) & Faeces; liver; lung \\
Toxoplasma spp. & Nested-PCR (Decaro et al. 2010) & Genital swab; pool of organ \\
& Nested-PCR (Vitale et al. 2013) & Muscle \\
Leishmania spp. & ELISA (ID Screen Toxoplasmosis Indirect Multipsecies, IDvet) & Serum; intra cardiac clot \\
& IFI (Internal method 15DG034.1.0) & Serum \\
Neospora caninum & RT-PCR (Vitale et al. 2004) & Lymphnode \\
\hline
\end{tabular}

\section{Foxes and mustelids}

From 2008 to 2018, a total of 89 carcasses of red fox and mustelids were collected within the territory of GPNP and stored at $-20{ }^{\circ} \mathrm{C}$. This included: $n=52$ red foxes, $n=16$ Eurasian badgers, $n=16$ beech martens, $n=3$ pine martens and $n=2$ stoats. Necropsy and diagnostic investigations were carried out by IZSPLV following standardized protocols (see next section and Table 1 for details).

\section{Analysis to assess the presence of pathogens}

Analyses focused on the identification of pathogens potentially dangerous for wildlife. For each species, a different diagnostic protocol was assessed, and biological samples (organ and tissue for carcasses and biological fluids and faeces for domestic dogs) were tested for Salmonella sp., Leptospira spp., Lyssavirus, canine distemper virus (CDV), canine Coronavirus (CCV), canine Parvovirus (CPV), canine Adenovirus (CAV), canine Herpesvirus (CHV), Toxoplasma spp. and Leishmania spp. Serological analyses were applied for the detection of immunoglobulin $\mathrm{G}$ (IgG) against CDV, Neospora caninum and Toxoplasma in blood samples using an enzyme-linked immunosorbent assay. Details about matrices, methods and test sensitivity and specificity are provided in Tables 1 and 2 .

\section{Data analysis}

\section{Disease prevalence}

For each of the disease tested, we estimated prevalence as the proportion of positive cases on the total number of animals tested (apparent prevalence). Where appropriate, prevalence is provided with 95\% CI adjusted for sensitivity and specificity. Adjustment was obtained following the asymptotic Wald method modified as described by Rogan and Gladen (1978) and Thrusfield (2007).

\section{Comparison between domestic dogs and wild species}

Pearson's chi-squared tests were used to assess the difference between the prevalence of infection with the following pathogens found in domestic dog and wild species: CDV, Leishmania sp., Toxoplasma gondii and Neospora caninum. As for Neospora caninum, prevalence data were missing for some of the categories; we only compared the categories for which data were available (i.e. shepherd dogs and Park rangers' dogs). To further investigate the differences in prevalence of infection with CDV, we performed pairwise comparison between the different categories (shepherd dogs, Park rangers' dogs, red foxes, mustelids). As this resulted in multiple testing, significance was assessed after Bonferroni correction. 
Table 2 Overall prevalence (with 95\% CI) of infections with selected pathogens in domestic dogs (a: shepherd dogs; b: Park rangers' dogs) and wild mammals (c: red fox; $d$ : mustelids). Where specificity SP and sensitivity SE are provided, 95\% CI were adjusted following Rogan and Gladen (1978) and Thrusfield (2007). When range values were available for SP and $\mathrm{SE}$, we used the lowest value provided

\begin{tabular}{|c|c|c|c|c|c|}
\hline Agent & Method & $\mathrm{N}$ tested & Positive & Prevalence & 95\% C.I \\
\hline \multicolumn{6}{|l|}{ a) Shepherd dogs } \\
\hline Canine distemper virus & ELISA (SP 100\% SE 99\%) & 52 & 34 & 0.65 & $0.52-0.77$ \\
\hline Canine parvovirus & PCR & 52 & 5 & 0.10 & $0.02-0.18$ \\
\hline Canine coronavirus & RT-PCR & 52 & 0 & 0.00 & $0.00-0.00$ \\
\hline Canine adenovirus $1-2$ & PCR & 52 & 0 & 0.00 & $0.00-0.00$ \\
\hline Canine herpesvirus & Nested PCR & 52 & 0 & 0.00 & $0.00-0.00$ \\
\hline Lyssavirus & Fluorescent Antibody Test & 52 & 0 & 0.00 & $0.00-0.00$ \\
\hline Leishmania sp. & IFI & 52 & 0 & 0.00 & $0.00-0.00$ \\
\hline Toxoplasma gondii & ELISA (SP 99.4\% SE 98.8\%) & 52 & 27 & 0.52 & $0.39-0.65$ \\
\hline Neospora caninum & ELISA (SP 99.5\% SE 96.6\%) & 52 & 19 & 0.37 & $0.25-0.49$ \\
\hline Leptospira sp. & Micro-agglutination & 52 & 3 & 0.06 & $0.01-0.12$ \\
\hline \multicolumn{6}{|l|}{ b) Park rangers' dogs } \\
\hline Canine distemper virus & ELISA (SP 100\% SE 99\%) & 25 & 21 & 0.84 & $0.65-0.94$ \\
\hline Canine parvovirus & PCR & 25 & 0 & 0.00 & $0.00-0.00$ \\
\hline Canine coronavirus & RT-PCR & 25 & 0 & 0.00 & $0.00-0.00$ \\
\hline Canine adenovirus $1-2$ & PCR & 25 & 0 & 0.00 & $0.00-0.00$ \\
\hline Canine herpesvirus & Nested PCR & 25 & 0 & 0.00 & $0.00-0.00$ \\
\hline Lyssavirus & Fluorescent Antibody Test & 25 & 0 & 0.00 & $0.00-0.00$ \\
\hline Leishmania sp. & IFI (SP 96.2\% SE 86.5\%) & 25 & 4 & 0.16 & $0.06-0.35$ \\
\hline Toxoplasma gondii & ELISA (SP 99.4\% SE 98.8\%) & 25 & 6 & 0.24 & $0.12-0.44$ \\
\hline Neospora caninum & ELISA (SP 99.5\% SE 96.6\%) & 25 & 2 & 0.08 & $0.02-0.25$ \\
\hline Leptospira sp. & Micro-agglutination & 25 & 0 & 0.00 & $0.00-0.00$ \\
\hline \multicolumn{6}{|l|}{ c) Red fox } \\
\hline Canine distemper virus & RT-PCR (SP 100\% SE 99\%) & 45 & 8 & 0.18 & $0.07-0.29$ \\
\hline Canine parvovirus & PCR & 45 & 0 & 0.00 & $0.00-0.00$ \\
\hline Canine coronavirus & RT-PCR & 45 & 0 & 0.00 & $0.00-0.00$ \\
\hline Canine adenovirus $1-2$ & PCR & 45 & 0 & 0.00 & $0.00-0.00$ \\
\hline Canine herpesvirus & Nested PCR & 45 & 0 & 0.00 & $0.00-0.00$ \\
\hline Lyssavirus & Fluorescent Antibody Test & 45 & 0 & 0.00 & $0.00-0.00$ \\
\hline Leishmania sp. & RT-PCR (SP 100\% SE 100\%) & 47 & 1 & 0.02 & $0.00-0.11$ \\
\hline Toxoplasma gondii & Nested PCR & 48 & 1 & 0.02 & $0.07-0.66$ \\
\hline Leptospira sp. & Nested PCR & 11 & 0 & 0.00 & $0.00-0.00$ \\
\hline Salmonella sp. & Bacteria culture & 47 & 2 & 0.04 & $0.00-0.10$ \\
\hline \multicolumn{6}{|l|}{ d) Mustelids } \\
\hline Canine distemper virus & RT-PCR (SP 100\% SE 99\%) & 33 & 2 & 0.06 & $0.02-0.20$ \\
\hline Canine parvovirus & PCR & 22 & 0 & 0.00 & $0.00-0.00$ \\
\hline Canine coronavirus & RT-PCR & 11 & 0 & 0.00 & $0.00-0.00$ \\
\hline Canine adenovirus $1-2$ & PCR & 34 & 0 & 0.00 & $0.00-0.00$ \\
\hline Lyssavirus & Nested PCR & 25 & 0 & 0.00 & $0.00-0.13$ \\
\hline Leishmania sp. & RT-PCR & 19 & 0 & 0.00 & $0.00-0.00$ \\
\hline Toxoplasma gondii & Nested PCR & 30 & 0 & 0.00 & $0.00-0.00$ \\
\hline Leptospira sp. & Nested PCR & 9 & 0 & 0.00 & $0.00-0.00$ \\
\hline Salmonella sp. & Bacteria culture & 28 & 3 & 0.11 & $0.00-0.22$ \\
\hline
\end{tabular}

\section{Results}

\section{Disease prevalence}

The prevalence (with 95\% CI) of the diseases tested for each species or group of species is provided in Table $2(\mathrm{a}-\mathrm{d})$ and described hereafter.

\section{Domestic dogs}

The prevalence of the diseases found in dogs is provided in Table 2 (a) (shepherd dog) and (b) (Park rangers' dog). Summed together, shepherd and Park rangers' dogs showed high prevalence of antibodies against CDV $(0.71 ; 95 \%$ CI 0.61-0.80), Toxoplasma gondii $(0.43 ; 95 \%$ CI $0.32-0.54)$ 
and Neospora caninum $(0.27 ; 95 \%$ CI 0.19-0.38). Part of the prevalence against distemper virus is due to the vaccination; however, 27 dogs were tested positive without vaccination ( $n=26$ shepherd dogs and $n=1$ Park rangers' dog).

Three shepherd dogs showed presence of antibodies against Leptospira (Leptospira saxkoebing: 1/77, L. bratislava: 1/77, and L. icterohaemorragie: $2 / 77 ; n=1$ dog was positive both to L. bratislava and L. icterohaemorragie). Two of them were tested again, after few months, and they all turn into negative. For one dog, it was impossible to repeat the exam because he died few weeks after our first sampling for suspected gastric dilatation. Five shepherd dogs were positive for CPV in faeces: three for type $2 a$, one for type $2 b$ and one for type $2 c$ : none of them were vaccinated. We found antibodies against Leishmania spp. in four Park rangers' dogs. However, as three of them were vaccinated (therefore, we hypothesized that the positivity was due to vaccination). No positivity to CAV, CCV, Lyssavirus, Herpesvirus, Salmonella spp. and Echinococcus granulosus was found (Table 2 (a and b)).

\section{Wild canids and mustelids}

The prevalence of the diseases found in wild canids and mustelids is provided in Table 2 (c) (red foxes) and (d) (mustelids). In both mustelids and red foxes CDV (10/78) and Salmonella veneziana (1/75), S. enterica subsp. diarizonae (2/75) and $S$. enteriditis (2/75) were detected. Two red foxes were positive to Toxoplasma gondii and Leishmania respectively. No positivity to CAV, CCV, Lyssavirus and Herpesvirus was recorded. It was not possible to test the samples for Leptospira sp. and Neospora sp. because of blood haemolysis.

\section{Comparison between domestic dogs and wild species}

Significant statistical difference in prevalence between categories was found for CDV, Toxoplasma, Neospora and Leishmania sp. (Table 3). For all those diseases, domestic dogs showed the highest prevalence (Table 2 (a and 2b)). Pairwise comparison between categories showed that

Table 3 Results of the Pearson's chi-squared test on the prevalence of infection with pathogens in domestic dog and wild species. Data on CVD, Leishmania sp. and Toxoplasma gondii prevalence were available for all categories (shepherd dogs, Park rangers' dogs, red foxes, mustelids); data on prevalence of Neospora caninum infection were available only for shepherd dogs and Park rangers' dogs

\begin{tabular}{lccr}
\hline Pathogen & $X$-squared & df & $p$-value \\
\hline CDV & 58.14 & 3 & $<0.001$ \\
Leishmania sp. & 14.41 & 3 & 0.002 \\
Toxoplasma gondii & 46.85 & 3 & $<0.001$ \\
Neospora caninum & 5.56 & 1 & 0.018 \\
\hline
\end{tabular}

Table 4 Pairwise comparison of prevalence of infection from CDV in different categories (shepherd dogs, Park rangers' dogs, red foxes, mustelids). n.s. non-significant differences

\begin{tabular}{lllll}
\hline & Shepherd dog & $\begin{array}{l}\text { Park } \\
\text { rangers' } \\
\text { dog }\end{array}$ & Red fox & Mustelids \\
\hline Shepherd dog & - & - & - & - \\
Park rangers' dog & n.s & - & - & - \\
Red fox & $*$ & $*$ & - & - \\
\hline
\end{tabular}

*Significant differences after Bonferroni correction $(p<0.008)$

CVD prevalence was significantly different between both domestic dog categories and red foxes (Table 4). Finally, the differences in prevalence between shepherd and Park rangers' dogs were never significant, except for Neospora infections, to which shepherd dogs were more frequently exposed (Table 3 ).

\section{Discussion}

Our study reports the presence and circulation of several pathogens shared between wildlife and domestic dogs. Hereafter, we discuss about their potential implications for wildlife conservation.

CDV was detected in biological samples of wild carnivores, and an active infection could be supposed. As reported by Di Blasio et al. (2019), during 2013-2015, an epidemic of CDV has occurred in wild carnivores in northwest Italy by the emergent CDV denoted as WE/06-09 cluster by Monne et al. (2011). Although we did not perform a phylogenetic analysis, the epidemiological context and previous data (Di Blasio et al. 2019) suggest the possibility that our findings, at least for wildlife, can be referred to this CDV epidemic. Our data revealed that over $70 \%$ of domestic dogs had antibodies against CDV. Considering that a non-negligible share of seropositive dogs has never been vaccinated, a subclinical form could be supposed according to Deem et al. (2000), that reports high prevalence of infection in domestic dogs without symptoms. However, an exposure to the virus and hence a spillover from wildlife cannot be excluded; even so, the absence of clinic disease in seropositive dogs may be related to the virus strain's strong specificity for wildlife (Di Blasio et al. 2019). Although CDV transmission usually occurs by direct contact, virus can survive for 2 days at $25^{\circ} \mathrm{C}$, or even longer at lower temperatures (Deem et al. 2000), and its high host plasticity allows the CDV to have a wide environmental distribution, being easily transmitted between species. As a matter of fact, natural and/or vaccine-induced CDV disease was reported in many wildlife species, not only in wild carnivores (Beineke et al. 2015). As widely 
described in literature, spill over of CDV led to huge consequences on wildlife conservation, as a result of generalized viral spread, severe clinical signs and mass mortalities (Harder and Osterhaus 1997; Deem et al. 2000; Beineke et al. 2015). The high prevalence detected in our study suggested that dogs could be victims but also a source of infection for native wild populations. For these reasons, their presence in an environment dedicated to wildlife conservation represents a threat as a possible source and spread of infection for a large number of endangered Alpine species especially for mustelids, since the high mortality induced by infection quickly eliminates sensitive individuals from the population (Tompkins et al. 2002). Despite the level of cross-immunity of vaccines in use is not clear (Beineke et al. 2015), dog vaccination remains the basic preventive measure to avoid spill over and spill back events, especially in those areas where there is a spatial overlap between domestic and wild carnivores.

Another highly contagious virus was detected in domestic dogs: the DNA of three types of CPV (2a-2b-2c) was found in the faecal swab of five dogs: CPV-2a and CPV-2b are the most widespread antigenic variants in the world and the CPV-2c, which is rapidly replacing CPV-2b, is also reported in Italy. Only shepherd dogs showed the presence of CPV, confirming their potential role as source of infection. All the wild carnivores investigated were negative for CPV-2; however, further investigations are necessary even using serology to ensure absence of disease.

For what concerned zoonoses, the prevalence values found in this study for Salmonella spp. in red fox and mustelids confirm the possible role of these species as reservoirs and/or as passive carriers of this pathogen as demonstrated also in a study conducted by Giorda et al. (2014) on animals (including foxes) hunted in western Liguria (Italy). Further investigation on the effect of the disease on wild species should be carried out in order to assess the risk for wildlife conservation.

The detection of antibodies against another agent of zoonosis, Leishmania spp., in vaccinated Park rangers' dogs was expected. On the contrary, the presence of antibodies in non-vaccinated dogs confirmed the wide distribution of this zoonotic agent in North West Italy (Millàn et al. 2014). Despite leishmaniosis is not currently considered a threat for Alpine mammals (Ferroglio et al. 2005), we can expect a change of this epidemiological situation with a potential increase of this disease due to global warming (Ferroglio et al. 2005). As a matter of fact, higher temperatures will reduce the vector winter mortality (phlebotomine sand flies), and new areas will become environmentally suitable for its survival and reproduction (Desjeux 2001).

As regards protozoa, the high prevalence of $N$. caninum recorded in domestic dogs in our study confirm the role of this species in the diffusion of this pathogen (Almeria 2013).
Most of the positive dogs were shepherd dogs probably due to the higher exposure to infection living in sympatry with livestock. Considering the widespread distribution of the parasite and the lack of investigations of its effects on many wild species, precaution suggests reducing as much as possible the frequency of direct and indirect contacts between the definitive host (domestic dog) and other sensitive species, especially those of conservation concern (Dubey et al. 2007). Preventive measures appear necessary as substantial increases in contact between wild dogs and domestic dogs are likely to increase pathogen exposure for wild dogs (Woodroffe et al. 2012).

The prevalence of another similar protozoa, $T$. gondii, in both shepherd and Park rangers' dogs in the study area, is slightly lower than that recorded for CDV. However, considering that dogs were not vaccinated against it, we can conclude that $T$. gondii is the most frequent pathogen in the examined sample. We supposed that this high prevalence was likely due to contact of domestic dogs with infected cats in rural or domestic environment since risk factors identified by many studies are cat related (Stelzer et al. 2019). Conversely, the prevalence recorded in red fox was lower than that reported in literature (Ferroglio et al. 2014). As described in other Alpine species, this low prevalence can be linked to the absence in the protected area of wild cats or lynx and to the high altitude of this area (and consequently, low density of human settlements), which involves a lower presence of domestic cats (Ferroglio et al. 2014).

Toxoplasma gondii (in association with $N$. caninum) was identified as a cause of reproductive failure in small ruminants (Ahmed et al. 2008; Dubey 2009; Dubey and Schares 2011; Moreno et al. 2012): abortion percentage up to $100 \%$ was reported in infected domestic sheep due to toxoplasmosis (Youngquist 1997). Despite the lack of specific studies on the effects of Toxoplasma gondii on reproductive success in wild ungulates, similar consequences may also occur in this taxon. For this reason, a high environmental contamination of this pathogen is to be considered as unfavourable for wildlife conservation.

Finally, some pathogens were not detected or detected with very low prevalence in our study. No serological prevalence was registered, neither in domestic nor in wild species, for $\mathrm{CCoV}$ and CAV: this suggested that these viruses are not, at present, circulating in the protected area. We also registered a very low prevalence for Leptospira suggesting that this pathogen is not widespread in dogs that frequent this alpine area. However, as feral and wild animals can be reservoir hosts for leptospires without any clinical sign (Bengis et al. 2004; Jardine et al. 2011), it is important to monitor this widespread zoonosis to underline the role of the domestic and wild canids that are dead-end hosts and good sentinels for the environmental epidemiological status (Millàn et al. 2009). 


\section{Conclusions}

Our results are clear and worrying, especially from a management point of view. Domestic dogs, which frequent an important protected area, could be potential shedder of three important pathogens as Canine distemper virus, Toxoplasma sp. and Neospora caninum. We sampled two categories of dogs that can have different roles in the transmission of diseases: shepherd dogs and Park rangers' dogs. Shepherd dogs are exposed to multiple pathogens because of their cohabitation with livestock besides a free-roaming and scavenging lifestyle: dogs in natural areas, indeed (alone or accompanied by humans), are stimulated by the environment and react similarly to their wild ancestors (Scott and Fuller 1974; Gompper 2013), thus potentially feeding also on carcasses. Furthermore, they are seldom subjected to veterinary care. Park rangers' dogs are instead regularly subjected to veterinary care and vaccination and are handled in a similar way to companion dogs. Therefore, their role in the ecology of diseases is expected to be similar to the role that of tourists' dog may potentially have: another study performed in the GPNP found no difference in prevalence of tick-borne pathogens between Park rangers' dogs and companion dogs especially allowed in the area (Gran Paradiso National Park, unpublished data). Our results suggest that despite shepherd dogs seeming to represent a more serious threat, both shepherd and Park rangers' dogs (and hence companion dogs) may act as potential spreaders of diseases, thus representing a threat for the conservation of wildlife in the protected area.

The prevalence values recorded in this study are particularly relevant when considering the management plan of the 15 mountain National Parks of Europe. The total ban for the access of domestic dogs is present only in one, the Swiss National Park, out of 15 National Parks existing in the Alps, while in all the other parks (93.3\%), working dogs (shepherd or dog for disabled) are allowed. The fact that tourists' dogs are allowed in $66.6 \%$ of the protected areas if they are kept on a leash means that most of the National Parks consider domestic dogs as a threat for wildlife only in respect of predation risk. No precautions to reduce the risk of transmission of infectious diseases between domestic and wild animals are instead included in National Park management regulation, with the only exception of the Swiss National Park, where all human activities were prohibited (Swiss National Park Protection Ordinance 498.200).

In our opinion, considering the results of our multispecies survey, in which domestic dogs appeared to be an important carrier of many dangerous pathogens for both wild carnivores and ungulates, their presence within the borders of strategic protected areas such as National Parks should be avoided. In particular, shepherd dogs seem to be a serious threat for wildlife. We acknowledge that this is a difficult decision to make by managers of protected areas also because domestic grazing is considered crucial for the conservation of open habitats, such as Alpine pasture and secondary grasslands, disadvantaged by global warming and human abandonment. Actually, most of Alpine protected areas allow-or even encourage - the presence of livestock and, consequently, of shepherd dogs. However, based on the health risks associated with the dog presence inside a National Park demonstrated by our study, we suggest the following management decisions: (i) minimization of the density of working dogs, in parallel with mass vaccination programs and integrated control measures (Cleaveland et al. 2006); (ii) prohibition of access to any other domestic dogs, even kept on a leash; (iii) use of the allowed domestic dogs as sentinel for wildlife infections, as well as for emerging human and livestock diseases. As suggested by Cleaveland et al. (2006), this precaution would minimize the negative effects of the presence of dogs, making them become part of the surveillance strategies to increase the efficiency of pathogen detection within wildlife sanctuary (Bowser and Anderson 2018).

Acknowledgements The authors would like to acknowledge the precious help of Dr. Marco Rondoletti during sampling operations in alpine pastures. We wish to thank also the support of the Surveillance service of the Gran Paradiso National Park and, of course, shepherds of Orco and Soana Valley for their hospitality and availability.

Availability of data and material All data generated or analysed during this study are included in this published article.

Code availability Code availability is not applicable to this article as no custom code was used to analyse the data.

\section{Declarations}

Ethics approval This study involved blood sampling from domestic dogs of shepherds and park rangers. The sampling protocol was assessed and approved by the biodiversity and scientific research service of Gran Paradiso National Park. The owners of the dogs included in the study provided their verbal informed consent for animal blood sampling. Collection of blood samples was carried out by veterinarians adhering to the regulations and guidelines on animal welfare.

Consent to participate This manuscript has been approved by all coauthors.

Consent for publication The authors grant the publisher the sole and exclusive license of the full copyright in the contribution.

Conflict of interest The authors declare no competing interests. 


\section{References}

Acosta-Jamett G, Chalmers WSK, Cunningham AA, Cleaveland S, Handel IG, de C Bronsvoort BM (2011) Urban domestic dog populations as a source of canine distemper virus for wild carnivores in the Coquimbo region of Chile. Vet Microbiol 152:247257. https://doi.org/10.1016/j.vetmic.2011.05.008

Acosta-Jamett G, Cunningham AA, Bronsvoort BMD et al (2015) Serosurvey of canine distemper virus and canine parvovirus in wild canids and domestic dogs at the rural interface in the Coquimbo Region, Chile. Eur J Wildl Res 61:329-332. https:// doi.org/10.1007/s10344-014-0886-0

Afema JA, Beckmen KB, Arthur SM, Huntington K, Mazet JAK (2017) Disease complexity in a declining Alaskan Muskos (Ovibos moschatus) population. J Wildl Dis 53:311-329. https://doi.org/10. 7589/2016-02-035

Ahmed YF, Sokkar SM, Desouky HM, Soror AH (2008) Abortion due to toxoplasmosis in small ruminants. Global Veterinaria 2:337-342

Alexander KA, Appel MJG (1994) African wild dogs (Lycaon pictus) endangered by a canine distemper epizootic among domestic dogs near the Masai Mara National Reserve, Kenya. J Wildl Dis 30:481-485. https://doi.org/10.7589/0090-3558-30.4.481

Almería S, Vidal D, Ferrer D, Pabón M, Fernández-de-Mera MIG, Ruiz-Fons F, Alzaga V, Marco I, Calvete C, Lavin S, Gortazar C, López-Gatius F, Dubey JP (2007) Seroprevalence of Neospora caninum in non-carnivorous wildlife from Spain. Vet Parasitol 143:21-28. https://doi.org/10.1007/s00436-017-5470-6

Almerìa S (2013) Neospora caninum and wildlife. IRSN Parasitology, 23 pp. Art. ID 947347. https://doi.org/10.5402/2013/947347

Appel MJG, Summers BA (1995) Pathogenicity of morbilliviruses for terrestrial carnivores. Vet Microbiol 44:187-191. https://doi.org/ 10.1016/0378-1135(95)00011-X

Aubert D, Ajzenberg RC, Gilot-Fromont E, Terrier ME, de Gevigney C, Game Y, Maillard D, Gibert P, Dardé ML, Villena I (2010) Molecular and biological characteristics of Toxoplasma gondii isolates from wildlife in France. Vet Parasitol 171:346-349. https://doi.org/10.1016/j.vetpar.2010.03.033

Ballash GA, Jenkins MC, Kwok OCH et al (2019) Effect of Urbanization on Neospora caninum seroprevalence in white-tailed deer (Odocoileus virginianus). EcoHealth 16:109-115. https://doi.org/ 10.1007/s10393-018-1390-x

Beineke A, Baumgartner W, Wohlsein P (2015) Cross-species transmission of canine distemper virus - an update. One Health 1:49-59

Bengis RG, Kock RA, Fischer J (2002) Infectious animal diseases: the wildlife/livestock interface. Rev Sci Tech 21:53-65. https:// doi.org/10.20506/rst.21.1.1322 (PMID: 11974630)

Bengis RG, Leighton FA, Fischer JR, Artois M, Mörner T, Tate CM (2004) The role of wildlife in emerging and re-emerging zoonoses. Rev Sci Tech 23:497-511 (PMID: 15702716)

Billinis C (2013) Wildlife diseases that pose a risk to small ruminants and their farmers. Small Rumin Res 110: 67-70, ISSN $0921-4488$

Bolin CA (2005) Leptospirosis in cattle: disease review and update. In: Proceeding of the NAVC. North American Veterinary Conference pp 8-12

Bowser N, Anderson NE (2018) Dogs (Canis familiaris) as sentinels for human infectious disease and application to canadian populations: a systematic review. Vet Sci 5:83

Bregoli M, Capelli G, Nardelli S, Cova M, Pasolli C (2006) Serological survey of Neospora caninum in free-ranging wild ruminants. Veterinarski Arhiv 76 (Suppl.):S111-S115

Buonavoglia C, Martella V, Pratelli A, Tempesta M, Cavalli A, Buonavoglia D, Bozzo G, Elia G, Decaro N, Carmichael L
(2001) Evidence for evolution of canine parvovirus type 2 in Italy. J Gen Virol 82:3021-3025. https://doi.org/10.1099/ 0022-1317-82-12-3021

Canuti M, Rodrigues B, Whitney HG, Lang AS (2017) Introduction of canine parvovirus 2 into wildlife on the Island of Newfoundland, Canada. Infect Genet Evol 55:205-208. https://doi. org/10.1016/j.meegid.2017.09.018

Carmichael LE, Greene CE (1998) Canine herpsesvirus infection. In: Greene CE (ed) Infectious diseases of the dog and cat, 2nd edn. W. B. Saunders Company, Philadelphia, Pennsylvania, pp 28-32

Cleaveland S, Appel MG, Chalmers WS, Chillingworth C, Kaare M, Dye C (2000) Serological and demographic evidence for domestic dogs as a source of canine distemper virus infection for Serengeti wildlife. Vet Microbiol 72:217-227. https://doi. org/10.1016/S0378-1135(99)00207-2

Cleaveland S, Laurenson MK, Taylor LH (2001) Diseases of humans and their domestic mammals: pathogen characteristics, host range and the risk of emergence. J Philosophical Transactions of the Royal Society of London. Series b: Biological Sciences 356:991-999. https://doi.org/10.1098/rstb.2001.0889

Cleaveland S, Magai K, Knobel D, Laurenson MK (2006) Canine vaccination-providing broader benefits for disease control. Vet Microbiol 117:43-50. https://doi.org/10.1016/j.vetmic.2006.04. 009

Cleaveland S, Meslin F, Breiman R (2006) Dogs can play useful role as sentinel hosts for disease. Nature 440:605. https://doi.org/ 10.1038/440605b. (PMID: 16572146)

Chaichan P, Mercier A, Galal L, Mahittikorn A, Ariey F, Morand S, Boumédiène F, Udonsom R, Hamidovic A, Murat JB, Sukthana Y, Dardé ML (2017) Geographical distribution of Toxoplasma gondii genotypes in Asia: a link with neighboring continents. Infect Genet Evol 53:227-238. https://doi.org/10.1016/j. meegid.2017.06.002

De Almeida Curi NH, Araújo AS, Campos FS et al (2010) Wild canids, domestic dogs and their pathogens in Southeast Brazil: disease threats for canid conservation. Biodivers Conserv 19:3513-3524. https://doi.org/10.1007/s10531-010-9911-0

Decaro N, Amorisco F, Desario C, Lorusso E, Camero M, Bellacicco AL et al (2010) Development and validation of a real-time PCR assay for specific and sensitive detection of canid herpesvirus 1 . J Virol Methods 169:176-180. https://doi.org/10.1016/j.jviromet. 2010.07.021

Deem SL, Spelman LH, Yates RA, Montali RJ (2000) Canine distemper in terrestrial carnivores: a review. J Zoo Wildl Med 31:441451. https://doi.org/10.1638/1042-7260(2000)031[0441: CDITCA]2.0.CO

Desjeux P (2001) The increase in risk factors for leishmaniasis worldwide. Trans R Soc Trop Med Hyg 95:239

Di Blasio A, Irico L, Caruso C, Miceli I, Robetto S, Peletto S, Varello $\mathrm{K}$, Giorda $\mathrm{F}$ et al (2019) Emerging distemper in northwest Italy: a multi-host pathogen in wild carnivores. J Wildl Dis 55: 000-000 (in press). https://doi.org/10.7589/2018-09-226

Donahoe SL, Lindsay SA, Krockenberger M, Phalen D, Šlapeta J (2015) A review of neosporosis and pathologic findings of Neospora caninum infection in wildlife. Int J Parasitol Parasites Wildl 4:216-238, ISSN 2213-2244

Dubey JP, Schares G, Ortega-Mora LM (2007) Epidemiology and control of neosporosis and Neospora caninum. Clin Microbiol Rev 20:323-367

Dubey JP (2009) Toxoplasmosis in sheep - the last 20 years. Vet Parasitol 163:1-14. https://doi.org/10.1016/j.vetpar.2009.02.026

Dubey JP, Schares G (2011) Neosporosis in animals-the last five years. Vet Parasitol 180:90-108

Ferroglio E, Rossi L (2001) Prevalence of Neospora caninum antibodies in wild ruminants from the Italian Alps. Vet Rec 148:754-755 
Ferroglio E, Maroli M, Gastaldo S, Mignone W, Rossi L (2005) Canine leishmaniasis, Italy. Emerg Infect Dis 11:1618-1620

Ferroglio E, Bosio F, Trisciuoglio A et al (2014) Toxoplasma gondii in sympatric wild herbivores and carnivores: epidemiology of infection in the Western Alps. Parasites Vectors 7:196. https:// doi.org/10.1186/1756-3305-7-196

Fiorello C, Deem S, Gompper M, Dubovi E (2004) Seroprevalence of pathogens in domestic carnivores on the border of Madidi National Park, Bolivia. Anim Conserv 7:45-54. https://doi.org/ $10.1017 /$ S 1367943003001197

Ford RB (2003) Infectious diseases: canine coronavirus. In: Schaer M (ed) Clinical medicine of the dog and cat. Iowa State Press, Ames, IA, pp 78-79

Gaffuri A, Giacometti M, Tranquillo VM, Magnino S, Cordioli P, Lanfranchi $P$ (2006) Serosurvey of roe deer, chamois and domestic sheep in the Central Italian Alps. J Wildl Dis 42:685-690

Gallana M, Ryser-Degiorgis MP, Wahli T, Segner H (2013) Climate change and infectious diseases of wildlife: altered interactions between pathogens, vectors and hosts. Current Zoology 59(3):427-437

Gamble DA, Lobbiani A, Gramegna M, Moore LE, Colucci G (1997) Development of a nested PCR assay for detection of feline infectious peritonitis virus in clinical specimens. J Clin Microbiol 35:673-675. https://doi.org/10.1128/JCM.35.3.673-675.1997

Gascoyne SC, Laurenson MK, Lelo S, Borner M (1993) Rabies in African wild dogs (Lycaon pictus) in the Serengeti Region, Tanzania. J Wildl Dis 29:396-402. https://doi.org/10.7589/00903558-29.3.396

Giorda F, Zoppi S, Mignone W, Grattarola C, Dondo A, Tittarelli C (2014) Salmonella infections in wild animals in Western Liguria. Trends in game meat hygiene. From forest to fork. Paulsen P et al (eds) Wageningen Academic Press: 161-166

Gompper ME (2013) Free-ranging dogs and wildlife conservation. Oxford University Press

Gortázar C, Ferroglio E, Höfle U et al (2007) Diseases shared between wildlife and livestock: a European perspective. Eur J Wildl Res 53:241-256. https://doi.org/10.1007/s10344-007-0098-y

Greene CE (1998) Infectious canine hepatitis and canine acidophil cell hepatitis. In: Greene CE (ed) Infectious diseases of the dog and cat, 2nd edn. W. B, Saunders Company, Philadelphia, Pennsylvania, pp 22-28

Greene CE, Rupprecht C (2013) Rabies and other lyssavirus infections. In: Greene CE (ed) Infectious diseases of the dog and cat, 4th edn. pp 179-2197

Grooms D (2006) Reproductive losses caused by bovine viral diarrhea virus and leptospirosis. Theriogenology 66:624-628

Harder TC, Osterhaus A (1997) Canine distemper virus - a morbillivirus in search of new hosts? Trends Microbiol 5:120-124. https://doi.org/10.1016/S0966-842X(97)01010-X

Haydon DT, Cleaveland S, Taylor LH, Laurenson MK (2002) Identifying reservoirs of infection: a conceptual and practical challenge. Emerg Infect Dis 8:1468-1473. https://doi.org/10.3201/ eid0812.010317

Heinse LM, Hardesty LH, Harris RB (2016) Risk of pathogen spillover to bighorn sheep from domestic sheep and goat flocks on private land. Wildl Soc Bull 40:625-633. https://doi.org/10. 1002/wsb.718

Hilbert F, Smulders FJM, Chopra-Dewasthaly R, Paulsen P (2012) Salmonella in the wildlife-human interface. Food Res Int 45:603-608. https://doi.org/10.1016/j.foodres.2011.08.015

Hill D, Chirukandoth S, Dubey J (2005) Biology and epidemiology of Toxoplasma gondii in man and animals. Anim Health Res Rev 6:41-61

Hoskins JD (1998) Canine coronaviral enteritis. In: Green CE (ed) Infectious Diseases of the Dog, and Cat. W. B. Saunders, Philadelphia, PA, pp 45-47
Hu R, Huang G, Qiu W et al (2001) Detection and differentiation of CAV-1 and CAV-2 by polymerase chain reaction. Vet Res Commun 25:77-84. https://doi.org/10.1023/A:1006417203856

Hudson MA, Young RP, Jackson JU, Orozco-terWengel P, Martin L, James A, Cunningham AA (2016) Dynamics and genetics of a disease-driven species decline to near extinction: lessons for conservation. Sci Rep 6(1):1-13

Jardine C, Lindsay LR, Nicholson VM, Ojkic D, Prescott JF (2011) Longitudinal study on the seroprevalence of avian influenza, leptospirosis, and tularemia in an urban population of raccoons (Procyon lotor) in Ontario. Canada Vector Borne Zoonotic Dis 11:37-42

Jokelainen P, Isomursu M, Nareaho A, Oksanen A (2011) Natural Toxoplasma gondii infections in European brown hares and mountain hares in Finland: proportional mortality rate, antibody prevalence and genetic characterization. J Wildl Dis 47:154-163

Jokelainen P, Nylund M (2012) Acute fatal Toxoplasmosis in three Eurasian red squirrels (Sciurus vulgaris) caused by genotype II of Toxoplasma gondii. J Wildl Dis 48:454-457. https://doi.org/ 10.7589/2013-03-057

Laurenson K, Sillero-Zubiri C, Thompson H, Shiferaw F, Thirgood S, Malcolm J (1998) Disease as a threat to endangered species: ethiopian wolves, domestic dogs and canine pathogens. Anim Conserv 1:273-280. https://doi.org/10.1111/j.1469-1795.1998. tb00038.x

Leendertz FH, Pauli G, Maetz-Rensing K, Boardman W, Nunn C, Ellerbrok H, Christophe B (2006) Pathogens as drivers of population declines: the importance of systematic monitoring in great apes and other threatened mammals. Biol Cons 131(2):325-337

Leighton FA, Working Group on Wildlife Diseases (2010) Training manual on wildlife diseases and surveillance. World organization for Animal Health

Lessa I, Guimarães TCS, de Godoy BH, Cunha A, Vieira EM (2016) Domestic dogs in protected areas: a threat to Brazilian mammals? Natureza \& Conservação 14:46-56. https://doi.org/10. 1016/j.ncon.2016.05.001

Loots AK, Mitchell E, Dalton DL, Kotzé A, Venter EH (2017) Advances in canine distemper virus pathogenesis research: a wildlife perspective. J Gen Virol 98:311-321. https://doi.org/ 10.1099/jgv.0.000666

Martinello F, Galuppo F, Ostanello F, Guberti V, Prosperi S (1997) Detection of canine parvovirus in wolves from Italy. J Wildl Dis 33:628-631. https://doi.org/10.7589/0090-3558-33.3.628

McCaw DL, Hoskins JD (2006) Canine viral enteritis. In: Greene CE (ed) Infectious diseases of the dog and cat, 3rd edn. Elsevier Inc., St. Louis, Missouri, pp 63-73

McKnight DT, Schwarzkopf L, Alford RA, Bower DS, Zenger KR (2017) Effects of emerging infectious diseases on host population genetics: A review. Conserv Genet 18:1235-1245

Mech LD, Goyal SM, Bota CN, Seal US (1986) Canine parvovirus infection in wolves (Canis lupus) from Minnesota. J Wildl Dis 22:104-106

Mech LD, Goyal SM (1993) Canine parvovirus effect on wolf population change and pup survival. J Wildl Dis 29:330-333

Mech LD, Goyal SM, Paul WJ et al (2008) Demographic effects of canine parvovirus on a free-ranging wolf population over 30 years. J Wildl Dis 44:824-836

Megid J, Souza VAF, Teixeira CR et al (2009) Canine distemper virus in a crab-eating fox (Cerdocyon thous) in Brazil. Case report and plylogenetic analyses. J Wildl Dis 45:527-530

Megid J, Teixeira CR, Amorin RL et al (2010) First identification of canine distemper virus in hoary fox (Lycalopex vetulus): pathologic aspects and virus phylogeny. J Wildl Dis 46:303-305

Millán J, Candela MG, López-Bao JV, Pereira M, Jiménez MA, LeónVizcaíno L (2009) Leptospirosis in wild and domestic carnivores 
in natural areas in Andalusia, Spain. Vector-Borne and Zoonotic Diseases 9:549-554

Millán J, Ferroglio E, Solano-Gallego L (2014) Role of wildlife in the epidemiology of Leishmania infantum infection in Europe. Parasitol Res 113:2005-2014. https://doi.org/10.1007/ s00436-014-3929-2

Monne I, Fusaro A, Valastro V, Citterio C, Pozza MD, Obber F, Cattoli G (2011) A distinct CDV genotype causing a major epidemic in Alpine wildlife. Vet Microbiol 150:63-69. https://doi.org/10. 1016/j.vetmic.2011.01.009

Moreno B, Collantes-Fernández E, Villa A, Navarro A, RegidorCerrillo J, Ortega-Mora LM (2012) Occurrence of Neospora caninum and Toxoplasma gondii infections in ovine and caprine abortions. Vet Pathol 187:312-318

Murray D, Kapke C, Evermann J, Fuller T (1999) Infectious disease and the conservation of free-ranging large carnivores. Anim Conserv 2:241-254. https://doi.org/10.1111/j.1469-1795.1999.tb00070.x

OIE (2008) In OIE Terrestrial manual, 2018. Chapter 3.1.12. - Leptospirosis. Accessed online https://www.oie.int/standard-setting/ terrestrial-manual/access-online/

OIE (2018a) In OIE Terrestrial manual, 2018. Chapter 3.9.8. - Salmonellosis. Accessed online https://www.oie.int/standard-setting/ terrestrial-manual/access-online/

OIE (2018b) In OIE Terrestrial manual, 2018. Chapter 3.1.17. - Rabies (infections with rabies virus) and other Lyssavirus https://www. oie.int/standard-setting/terrestrial-manual/access-online/

Oleaga A, Zanet S, Espí A, Pegoraro de Macedo MR, Gortázar C, Ferroglio E (2018) Leishmania in wolves in northern Spain: a spreading zoonosis evidenced by wildlife sanitary surveillance. Vet Parasitol 255:6-31

Palmegiani I, Gazzola A, Apollonio M (2013) Wolf diet and its impact on the ungulates community in a new recolonized area of Western Alps: Gran Paradiso National Park. J Vertebr Biol 62:59-66

Panadero R, Painceira A, Lòpez C, Vàzquez L, Paz A, Dìaz P, Dacal V, Cienfuegos $\mathrm{S}$, Fernàndez $\mathrm{G}$, Lago $\mathrm{N}$, Dìez-Baños $\mathrm{P}$, Morrondo $\mathrm{P}$ (2010) Seroprevalence of Toxoplasma gondii and Neospora caninum in wild and domestic ruminants sharing pastures in Galicia (Northwest Spain). Res Vet Sci 88: 111-115, ISSN 0034-5288

Patriarca E, Debernardi P (1997) Insectivora, Chiroptera, Lagomorpha, Rodentia and Carnivora of the Gran Paradiso National Park: checklist and preliminary ecological characterization. J Mount Ecology 4:17-32

Pedersen AB, Jones KE, Nunn CL, Altizer SA (2007) Infectious disease and mammalian extinction risk. Conserv Biol 21:1269-1279

Pollock RV, Carmichael LE, Appel MJ (1980) Canine parvovirus summary. J Am Vet Med Assoc 177:619

Pratelli A, Tempesta M, Greco G, Martella V, Buonavoglia C (1999) Development of a Nested PCR Assay for the detection of Canine Coronavirus. J Virol Methods 80:11-15. https://doi. org/10.1016/s0166-0934(99)00017-8

Randall LZ, Dubey JP, Kwok OCH, Jay MVH (2000) Serologic survey for Toxoplasma gondii in selected wildlife species from Alaska. J Wildl Dis 36:219-224. https://doi.org/10.7589/00903558-36.2.219

Randall DA, Williams SD, Kuzmin IV, Rupprecht CE, Tallents LA, Tefera Z, Argaw K, Shiferaw F, Knobel DL, Sillero-Zubiri C, Laurenson MK (2004) Rabies in endangered Ethiopian wolves. Emerg Infect Dis 10:2214-2217. https://doi.org/10.3201/eid1012.040080

Rizzoli A, Tagliapietra V, Cagnacci F, Marini G, Arnoldi D, Rosso F, Rosà R (2019) Parasites and wildlife in a changing world: the vector-host-pathogen interaction as a learning case. International Journal for Parasitology: Parasites and Wildlife 9:394-401

Rogan WJ, Gladen B (1978) Estimating prevalence from the results of a screening test. Am J Epidemiol 107:71-76
Scott JP, Fuller JL (1974) Dog behavior. University of Chicago Press

Saif LJ, Heckert RA (1990) Enteropathogenic coronaviruses: canine coronavirus. In: Saif LJ, Theil KW (eds) Viral diarrheas of man and animals. CRC Press, Boca Raton, FL, pp 204-208

Salb AL, Barkema HW, Elkin BT, Thompson RC, Whiteside DP, Black SR, Dubey JP, Kutz SJ (2008) Dogs as sources and sentinels of parasites in humans and wildlife, northern Canada. Emerg Infect Dis Jan 141:60-3. https://doi.org/10.3201/eid1401.071113

Scheele BC, Pasmans F, Skerratt LF, Berger L, Martel AN, Beukema W, Canessa S (2019) Amphibian fungal panzootic causes catastrophic and ongoing loss of biodiversity. Science 363(6434):1459-1463

Smith KF, Sax DF, Lafferty KD (2006) Evidence for the role of infectious disease in species extinction and endangerment. Conserv Biol 20:1349-1357. https://doi.org/10.1111/j.1523-1739.2006. 00524.X

Smith KF, Acevedo-Whitehouse K, Pedersen AB (2009) The role of infectious diseases in biological conservation. Anim Conserv 12:1-12. https://doi.org/10.1111/j.1469-1795.2008.00228.x

Souza TD, Turchetti AP, Fujiwara RT, Paixão TA, Santos RL (2014) Visceral leishmaniasis in zoo and wildlife. Vet Parasitol 200:233-241. https://doi.org/10.1016/j.vetpar.2013.12.025

Steinel A, Parrish CR, Bloom EM, Truyen U (2001) Parvovirus infections in wild carnivores. J Wildl Dis 37:594-607. https://doi.org/ 10.7589/0090-3558-37.3.594

Stelzer S, Basso W, Benavides Silván J, Ortega-Mora LM, Maksimov P, Gethmann J, Conraths FJ, Schares G (2019) Toxoplasma gondii infection and toxoplasmosis in farm animals: risk factors and economic impact. Food and Waterborne Parasitology 15:e0037. https://doi.org/10.1016/j.fawpar.2019.e00037

Sterl P, Brandenburg C, Arnberger A (2008) Visitors awareness and assessment of recreational disturbance of wildlife in the DonauAuen National Park. J Nat Conserv 16:135-145

Stoddarda RA, Gee JE, Wilkins PP, Mc Caustland K, Hoffmaster AR (2009) Detection of pathogenic Leptospira spp. through TaqMan polymerase chain reaction targeting the LipL32 gene. Diagn Microbiol Infect Dis 64:247-255

Swiss National Park Protection Ordinance 498.200. https://www.natio nalpark.ch/en/visit/hiking/protection-regulations/

Tennant BJ, Gaskell RML, Kelly DF, Carter SD, Gaskell CJ (1993) Studies on the epizootiology of canine coronavirus. Vet Rec 132:7-11

Thrusfield MV (2007) Veterinary epidemiology. Wiley-Blackwell, New York, p 610

Timm SF, Munson L, Summers BA, Terio KA, Dubovi EJ, Rupprecht CE, Kapil S, Garcelon DK (2009) A suspected canine distemper epidemic as the cause of a catastrophic decline in Santa Catalina Island foxes (Urocyon littoralis catalinae). J Wildl Dis 45:333-343

Tompkins DM, Dobson AP, Arneberg P, Begon ME et al (2002) Parasites and host population dynamics. In: Hudson PJ, Rizzoli A, Grenfell BT, Heesterbeek H, Dobson AP (eds). The Ecology of Wildlife Diseases. Oxford University Press, Oxford. Chapter 3: $45-62$

Valière N, Fumagalli L, Gielly L et al (2003) Long distance wolf recolonization of France and Switzerland inferred from non-invasive genetic sampling over a period of 10 years. Anim Conserv 6: $83-92$

Vitale F et al (2004) TaqMan-based detection of Leishmania infantum DNA using canine samples. Ann N.Y. Acad Sci 1026:139-143

Vitale M, Galluzzo P, Currò V, Gozdzik K, Schillaci D, Di Marco Lo Presti V (2013) A high sensitive nested PCR for Toxoplasma gondii detection in animal and food samples. Appl Microbiol Biotechnol 5:2. https://doi.org/10.4172/1948-5948.1000097

Walsh J (2011) Unleashed fury: the political struggle for dog-friendly parks. Purdue University Press, West Lafayette 
Watts DE, Benson AM (2016) Prevalence of antibodies for selected canine pathogens among wolves (Canis Lupus) from the Alaska Peninsula, USA. J Wildl Dis 1 July 52: 506-515. https://doi.org/ 10.7589/2015-06-140

Woodroffe R, Cleaveland S, Courtenay O et al (2004) Infectious disease. In: Macdonald DW, Sillero-Zubir C (eds). The Biology and Conservation of wild canids. Oxford University Press, Oxford. Chapter 6: p 124

Woodroffe R, Prager KC, Munson L, Conrad PA, Dubovi EJ et al (2012) Contact with domestic dogs increases pathogen exposure in endangered African wild dogs (Lycaon pictus). PLoS One 7(1):e30099. https://doi.org/10.1371/journal.pone.0030099 Younquist RS (1997) Current therapy in large animal Theriogenology. Textbook, W.B. SaundersCompany, Philadelphia, USA

Publisher's Note Springer Nature remains neutral with regard to jurisdictional claims in published maps and institutional affiliations. 